Article

\title{
Improvement of Postharvest Quality of Plum (Prunus domestica L.) Using Polysaccharide-Based Edible Coatings
}

\author{
Sima Panahirad ${ }^{1}\left(\mathbb{D}\right.$, Rahim Naghshiband-Hassani ${ }^{1}$, Sara Bergin ${ }^{2}$, Ramesh Katam ${ }^{2, *(\mathbb{D}}$ and \\ Nasser Mahna ${ }^{1, * \mathbb{D}}$ \\ 1 Department of Horticultural Sciences, Faculty of Agriculture, University of Tabriz, Tabriz 5166616471, Iran; \\ sima.panahirad@gmail.com (S.P.); rahnaghsh@yahoo.com (R.N.-H.) \\ 2 Department of Biological Sciences, Florida A\&M University, Tallahassee, FL 32307, USA; \\ sara.bergin@gmail.com \\ * Correspondence: ramesh.katam@famu.edu (R.K.); mahna@tabrizu.ac.ir (N.M.); \\ Tel.: +98-41-3339-2027 (N.M.)
}

Received: 29 July 2020; Accepted: 1 September 2020; Published: 4 September 2020

\begin{abstract}
Polysaccharide-based edible coatings are served as an attractive preservation method for postharvest maintenance of most fruits. The current study examined the effect of carboxymethylcellulose (CMC)- and pectin (Pec)-based edible coatings on titratable acidity (TA), firmness; vitamin C (vit C); total soluble solids (TSS); $\mathrm{pH}$; total phenolics; anthocyanin and flavonoid contents; total antioxidant capacity (based on 1,1-Diphenyl-2-picryl-hydrazyl hydrate (DPPH)); the activities of peroxidase (POD), polyphenol oxidase (PPO) and polygalacturonase (PG) enzymes; and weight loss during cold storage. The results showed that each coating and their combinations caused positive effects in all measured parameters except weight loss. The applied coatings preserved firmness and improved total phenols, anthocyanin and flavonoid contents, antioxidant capacity and POD activity. In addition, TSS decreased and $\mathrm{pH}$ values remained more or less stable with the coating application. The coatings delayed TA and vitamin C loss, and decreased enzymatic activities such as PPO and PG. It could be stated that $\mathrm{CMC}$ at $1 \%$ and Pec at $1.5 \%$ separately demonstrated the best results for most of the measured parameters; and $0.5 \%$ Pec $+1.5 \%$ CMC could be considered as the best combination. In conclusion, application of $\mathrm{CMC}, \mathrm{Pec}$, or their combinations would be considered as an interesting approach to improve postharvest quality characteristics of plum fruit.
\end{abstract}

Keywords: carboxymethylcellulose; pectin; plum; qualitative attributes; enzymatic activity; postharvest

\section{Introduction}

Fruits and vegetables are a great source of antioxidants, anthocyanins, phenolics, some vitamins and nutritional elements [1] which are associated with reduced risk of chronic health disorders [2,3]. Plums (Prunus domestica L.) are an important fruit, among the functional foods and nutraceuticals. Plums are a good source of antioxidants. They might help the human body to fight various diseases. However, plums have short postharvest life that results in loss of valuable and nutritional elements [4]. Plums quality rapidly declines after harvesting due to their high respiration rate. Consequently, after transportation and marketing process, they often do not reach consumers at their best status $[5,6]$.

In recent years, applications of safer methods for fruit preservation are of a high significance. These safe methods usually have neither side effects on human and animal health, nor negative influences on the environment. Edible coatings are considered as one of the safe strategies. Edible coatings could improve fruit postharvest. So, application of edible coatings with natural origin such as proteins and polysaccharides has received a growing interest $[7,8]$. 
Polysaccharide-based edible coatings act as efficient oxygen blockers due to their well-arranged hydrogen bonded network structure but not as moisture barriers. The coatings are commonly colorless, oil-free and with low caloric content that often prolong the postharvest storability of fruit by reducing the dehydration and oxidative rancidity [7]. Moreover, polysaccharide-based edible coatings are highly stable, safe, nontoxic and biodegradable. Cellulose derivatives and pectin are two main groups of polysaccharide-based edible coatings [9].

Carboxymethylcellulose $(\mathrm{CMC})$ is a cellulose derivative, anionic, linear, long-chain and high molecular weight compound [10,11]. CMC-based coatings mostly do not have odor, taste, and any toxic or allergic effects. They also are biodegradable, flexible, transparent, oil resistant, soluble-in-water and slightly permeable to oxygen, $\mathrm{CO}_{2}$, and moisture [12].

Pectin (Pec), main compound of plant cell walls, is a complex high molecular weight polysaccharide with branching structure [13,14], and an amorphous and colloidal carbohydrate [14]. Pec-based coatings are excellent barriers to $\mathrm{O}_{2}$ and $\mathrm{CO}_{2}$, in addition to their transparency, oil-resistance, and water solubility. They prevent moisture loss to some extent and eventually maintain the sensory aspects and quality of foods $[14,15]$.

CMC-based edible coatings have been shown to be efficient in preserving postharvest quality of pear, papaya, mandarin and peach [16-19]. Pec-based ones preserved quality of peach, nectarine, fresh-cut apple, and persimmon [20-23]. Some studies reported the application of edible coatings on plum fruit, including chitosan [24], and carboxymethylcellulose, alone [8] or in combination with irradiation [6].

Given this background, few studies were performed using these polysaccharide-based edible coatings (CMC and Pec) on plum fruit during cold storage. CMC-based edible coatings (with the best effect at $1 \%$ ) were effective in maintaining firmness and nutritional attributes (e.g., titratable acidity (TA), vitamin C (vit C), anthocyanin, flavonoid, antioxidant activity), decreasing polyphenol oxidase (PPO) and polygalacturonase (PG) and increasing peroxidase (POD) enzymes activities in plum during shelf life [8]. Moreover, no report of combination of the two coatings was observed on plum fruit. Accordingly, this study aims to investigate the influence of CMC- and Pec-based edible coatings, alone and combined, on some postharvest qualitative and enzymatic activities of plum in order to reduce postharvest losses of this fruit. Furthermore, the current survey might be a comprehensive evaluation of different qualitative characters especially antioxidant contents and enzymatic behavior of coated plum during cold storage.

\section{Materials and Methods}

\subsection{Plant Materials}

Fruits (Prunus domestica cv. "Golden Drop") were obtained from an orchard in northwest of Iran (Shabestar) at their harvest stage ( $\approx 85$ days after full bloom). They were ripe, firm, uniform in size and maturity and had an acceptable amount of TSS/TA with no damage or scar. The fruits, after washing with distilled water, were put on paper towels at room temperature to dry out and then coated with different polysaccharides.

\subsection{Coating Treatments of Fruits}

The experiment was done using three concentrations (0.5, 1 and $1.5 \%)$ of carboxymethylcellulose (CMC) and pectin (Pec) (Sigma Aldrich Chemic, Steinhein, Germany), both alone and in combination (total 16 including control and 15 treatments) (Table 1) in three replications and with sixty fruits for each replication.

Sampling was performed at weekly intervals for six weeks, 10 fruits per each sampling ( 30 fruits for each measurement). Coating treatment solutions ( $\mathrm{CMC}$ and $\mathrm{Pec}$ ) were obtained by dissolving them in purified water, while mixing at $60{ }^{\circ} \mathrm{C}$, and glycerol $0.3 \%$ was added to plasticize the combination and then mixed again. Then, plum fruit were sunk in the homogenized solutions for $60 \mathrm{~s}$ and put 
at room temperature for one hour to dry. Subsequently, they were maintained at $4{ }^{\circ} \mathrm{C}$ and $85 \pm 5 \%$ relative humidity on open plastic grids for six weeks. The control non-coated fruits were treated with purified water for $60 \mathrm{~s}$.

Table 1. Treatment combinations of carboxymethylcellulose (CMC) (\%) and pectin (Pec) (\%) on fruits.

\begin{tabular}{cccccc}
\hline & & \multicolumn{4}{c}{ CMC } \\
\hline \multirow{4}{*}{ Pec } & 0 & 1 & 2 & 3 & 4 \\
& 0.5 & 5 & 6 & 7 & 8 \\
& 1.0 & 9 & 10 & 11 & 12 \\
& 1.5 & 13 & 14 & 15 & 16 \\
\hline
\end{tabular}

\subsection{Evaluation of Fruit Quality}

2.3.1. Measurement of Titratable Acidity (TA), Firmness, Vitamin C (vit C), Total Soluble Solids (TSS), $\mathrm{pH}$, and Weight Loss

Titratable acidity was quantified through titration with $0.1 \mathrm{~N} \mathrm{NaOH}$ up to $\mathrm{pH}$ 8.1. Firmness was assessed on both sides of peeled fruits utilizing 8-mm plunger of a manual penetrometer (Effegi, Milan, Italy). The vitamin $C$ content of the fruit samples was verified by making use of a titrimetric method on the basis of the reduction of 2,6-dichlorophenolindophenol dye, as explained by AOAC [25]. A refractometer (PR-1; Atago Co., Ltd., Tokyo, Japan) was used to determine the TSS of the samples at $20{ }^{\circ} \mathrm{C}$ (expressed as \%). A pH meter (Hanna Instruments, Milan, Italy) was used to record $\mathrm{pH}$ of the samples. Homogenized fruit samples (10 fruits) were used for measuring TSS, TA, and vit C. The results of TA and vit $C$ were reported as $\mathrm{g} \mathrm{kg}^{-1}$ on the basis of fresh weight. Percentage loss of initial weight was calculated as a unit for measuring weight loss. For each measurement, three technical replicates were included.

\subsubsection{Total Phenolic Compounds, Total Anthocyanin, and Flavonoid Contents}

Total phenolic compounds were determined using Folin-Ciocalteu reagent as reported by Singleton and Rossi [26]. Briefly, $1 \mathrm{~g}$ of the fleshy fruit was digested in $2 \mathrm{~mL} 1 \% \mathrm{HCl}$-methanol and centrifuged with a Universal 320R centrifuge (Andreas Heittich GmbH \& Co., Tuttlingen, Germany) at 8000× $g$ at $4{ }^{\circ} \mathrm{C}$ for $10 \mathrm{~min}$. Then, the supernatant was utilized to measure the total phenolic compounds. To do this, $450 \mathrm{~mL}$ of distilled water and $2.5 \mathrm{~mL}$ of $10 \%$ Folin-Ciocalteu solution were added to $50 \mathrm{~mL}$ of extract and incubated in darkness. Then, the absorbance data were collected after $1.5 \mathrm{~h}$ incubation in darkness at $760 \mathrm{~nm}$ employing a Spekol 1500 spectrophotometer (Analytik Jena AG, Jena, Germany). The absorbance data were used to calculate the total phenolics and stated as $\mathrm{g} \mathrm{kg}^{-1}$ gallic acid on the basis of fresh weight. A range of concentrations (50-500 $\mu \mathrm{g} \mathrm{mL}^{-1}$ ) of gallic acid in $95 \%$ methanol was utilized as standard. The flesh and peel $(1 \mathrm{~g})$ of the fruit samples were properly sliced and used to extract anthocyanins in $2 \mathrm{~mL}$ of $1 \% \mathrm{HCl}$-methanol, and finally the extract was exploited to estimate the total anthocyanin content, as previously reported [27]. After centrifuging, the absorbance of the extract was quantified at $530 \mathrm{~nm}$ to calculate the total anthocyanin content as absorbance at $530 \mathrm{~nm} \mathrm{~g}^{-1}$ on a fresh weight basis. Total flavonoid content was determined according to the Woisky and Salatino method [28] with some modifications. Briefly, $1 \mathrm{~g}$ of peel and flesh of fruit samples were used to extract flavonoids in $4 \mathrm{~mL} 96 \%$ ethanol. After centrifuging, $700 \mu \mathrm{L} 96 \%$ ethanol, $100 \mu \mathrm{L} 10 \%$ aluminum chloride, $100 \mu \mathrm{L} 1 \mathrm{M}$ potassium acetate and at last $2.8 \mathrm{~mL}$ distilled water were added to $1300 \mu \mathrm{L}$ of the extract (supernatant). Then, the absorbance of the solution was recorded at $415 \mathrm{~nm}$ after $30 \mathrm{~min}$ at room temperature. The findings were stated as $\mathrm{g} \mathrm{kg}^{-1}$ quercetin on the basis of fresh weight. For standards, a range of quercetin concentrations $\left(100-1000 \mu \mathrm{g} \mathrm{mL}^{-1}\right)$ was used. 


\subsubsection{Total Antioxidant Activity}

The method, 1,1-Diphenyl-2-picryl-hydrazyl hydrate (DPPH), was used to verify the antioxidant activity. One gram of flesh and peel from fruit samples were chopped and extracted in $2 \mathrm{~mL}$ of $1 \%$ $\mathrm{HCl}$-methanol and centrifuged subsequently [29]. Absorbance data were recorded at $517 \mathrm{~nm}$ after $15 \mathrm{~min}$ and the activity was analyzed and stated as percentage (\%) using the formula:

$$
\% \text { Total antioxidant activity }=\left(A_{\text {blank }}-A_{\text {sample }}\right) /\left(A_{\text {blank }}\right) \times 100
$$

\subsubsection{Peroxidase (POD), Polyphenol Oxidase (PPO) and Polygalacturonase (PG) Activities}

One gram of flesh and peel from each fruit sample were smashed and extracted in $3 \mathrm{~mL}$ of $0.1 \mathrm{M}$ phosphate buffer in an ice bath. After centrifugation, the supernatant was used as the crude enzyme extract. The activity of POD was evaluated according to the method explained by Arnnok et al. [30] with some modifications. The enzyme activity was assessed in $2 \mathrm{~mL}$ reaction mixture containing $0.1 \mathrm{M}$ phosphate buffer, guaiacol, extract and $\mathrm{H}_{2} \mathrm{O}_{2}$. Guaiacol oxidation was examined by monitoring the increase in absorbance at $470 \mathrm{~nm}$. The resulted data were stated as $\mu \mathrm{mol}$ tetraguaiacol min ${ }^{-1} \mathrm{~g}^{-1}$ on a fresh weight basis. The activity of PPO was calculated according to Jiang et al method [27] with modifications. A reaction mixture of $0.1 \mathrm{M}$ phosphate buffer, $1 \mathrm{M}$ 4-methylcatechol and enzyme solution was used to perform the PPO enzyme activity assay monitoring the upsurge in absorbance at $420 \mathrm{~nm}$ recorded for $90 \mathrm{~s}$. The resulted data were expressed as $\mu \mathrm{mol}$ oxidized catechol $\mathrm{min}^{-1} \mathrm{~g}^{-1}$ on a fresh weight basis.

The activity of polygalacturonase enzyme was determined on the basis of the reducing groups released by PG and quantified by spectrophotometer [31]. One gram of flesh and peel from each fruit sample was smashed in $3 \mathrm{~mL}$ of $50 \mathrm{mM}$ sodium acetate buffer and after centrifugation, $950 \mathrm{~mL}$ sodium acetate buffer and $1 \mathrm{~mL} 0.3 \%$ polygalacturonic acid were added to the supernatant $(50 \mathrm{~mL})$ and then the mixture was put at $30^{\circ} \mathrm{C}$ for $45 \mathrm{~min}$. Subsequently, the reaction mixture was stopped by boiling for $10 \mathrm{~min}$ after adding $800 \mathrm{~mL} 0.1 \mathrm{M}$ borate buffer ( $\mathrm{pH} 9.0$ ) at $0{ }^{\circ} \mathrm{C}$ and $200 \mathrm{~mL}$ of $1 \%$ cyanoacetamide solution. After lowering the temperature, the absorbance at $276 \mathrm{~nm}$ was recorded. PG activity was noted as $\mu \mathrm{mol} \mathrm{D}$-galacturonic acid $\mathrm{min}^{-1} \mathrm{~g}^{-1}$ on the basis of fresh weight.

\subsection{Statistical Analysis}

The study was carried out as a completely randomized design-based factorial experiment. After collecting data, subjects were assumed as a random factor and time as the repeated measure in a linear mixed model with Pec, CMC and time as fixed factors for a full factorial analysis of variance using the software IBM SPSS Statistics (version 21, SPSS Inc., Chicago, IL, USA). Marginal means were estimated based on maximum likelihood and least significant difference adjustment for multiple comparisons was done at $p \leq 0.05$ and ultimately, these estimated marginal means were reported and their $95 \%$ confidence intervals were illustrated as error bars in the given graphs.

\section{Results}

\subsection{TA, Firmness, vit $C, T S S, p H$ and Weight Loss}

Pec coating did not reduce TA content (Figure 1a), whereas CMC slightly increased TA values compared to the control (Figure 1b). All Pec and CMC combinations (except $1 \% \mathrm{Pec}+1.5 \% \mathrm{CMC} \approx$ $14.57 \mathrm{~g} \mathrm{~kg}^{-1}$ ) maintained TA contents of coated fruit with the high TA at $0.5 \%$ Pec $+1 \%$ CMC $(\approx 16.44)$ and $1.5 \%$ Pec $+1.5 \% \mathrm{CMC}\left(\approx 16.35 \mathrm{~g} \mathrm{~kg}^{-1}\right)$ (Figure 1c).

$\mathrm{Pec}, \mathrm{CMC}$, and their combinations significantly increased the firmness of plum. In particular, the best results were achieved with 1.5\% Pec $(\approx 12.556 \mathrm{~N})$ (Figure 2a), 1\% CMC ( $\approx 12.31)$ (Figure 2b), and the combination $1.5 \% \mathrm{Pec}+1 \% \mathrm{CMC}(\approx 14.495 \mathrm{~N})$ (Figure 2c). 

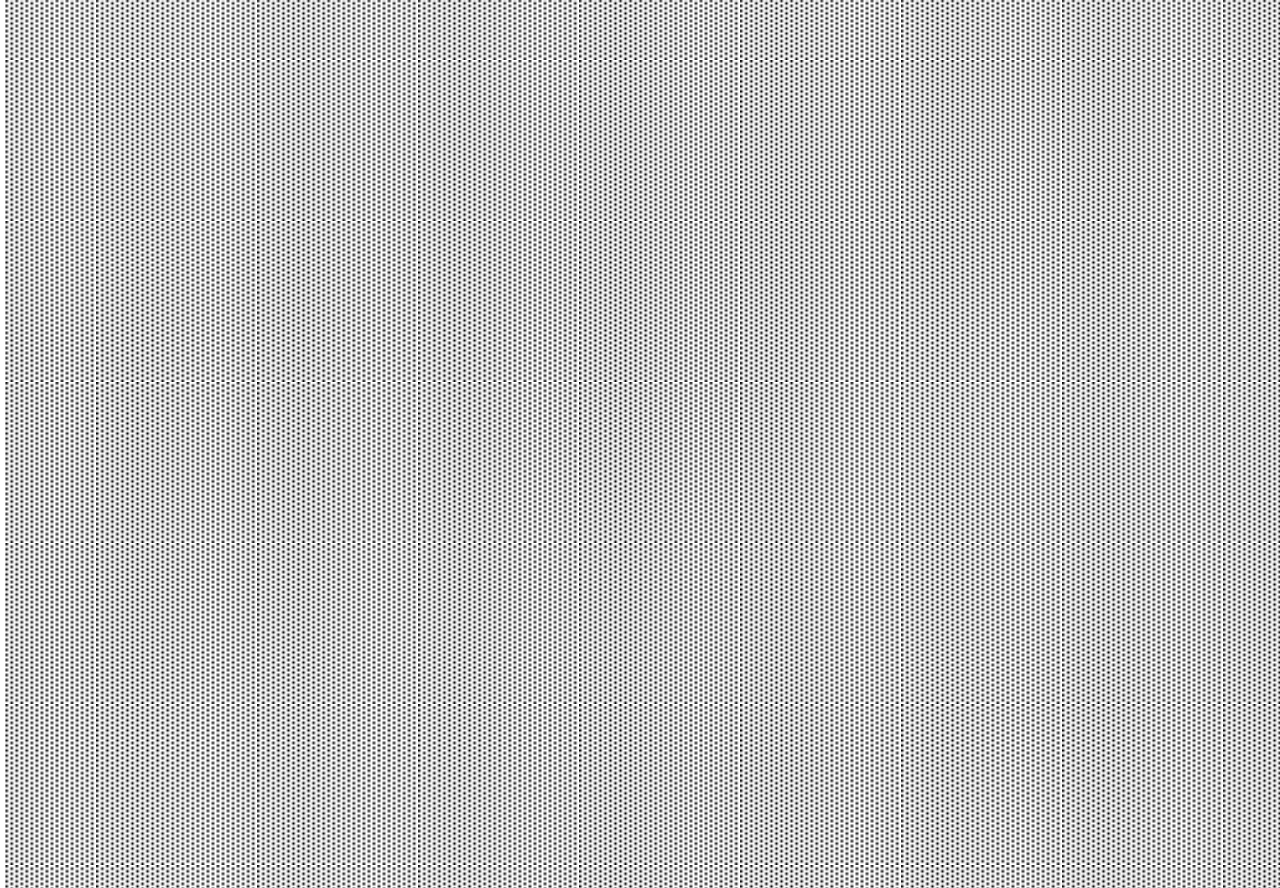

Figure 1. Effect of 0 (control), $0.5(0.5 \% \mathrm{Pec}), 1(1 \% \mathrm{Pec})$ and $1.5(1.5 \% \mathrm{Pec}) \%$ pectin-based edible coatings (a), 0 (control), 0.5 (0.5\% CMC), 1 (1\% CMC) and 1.5 (1.5\% CMC) \% carboxymethylcellulose-based edible coatings (b) and their combinations (c) on TA (titratable acidity) content during cold storage period. Data are the "estimated marginal means $\pm 95 \%$ confidence intervals". The results were expressed on a fresh weight basis. The columns with non-overlapping error bars are significantly different $(p \leq 0.05)$.
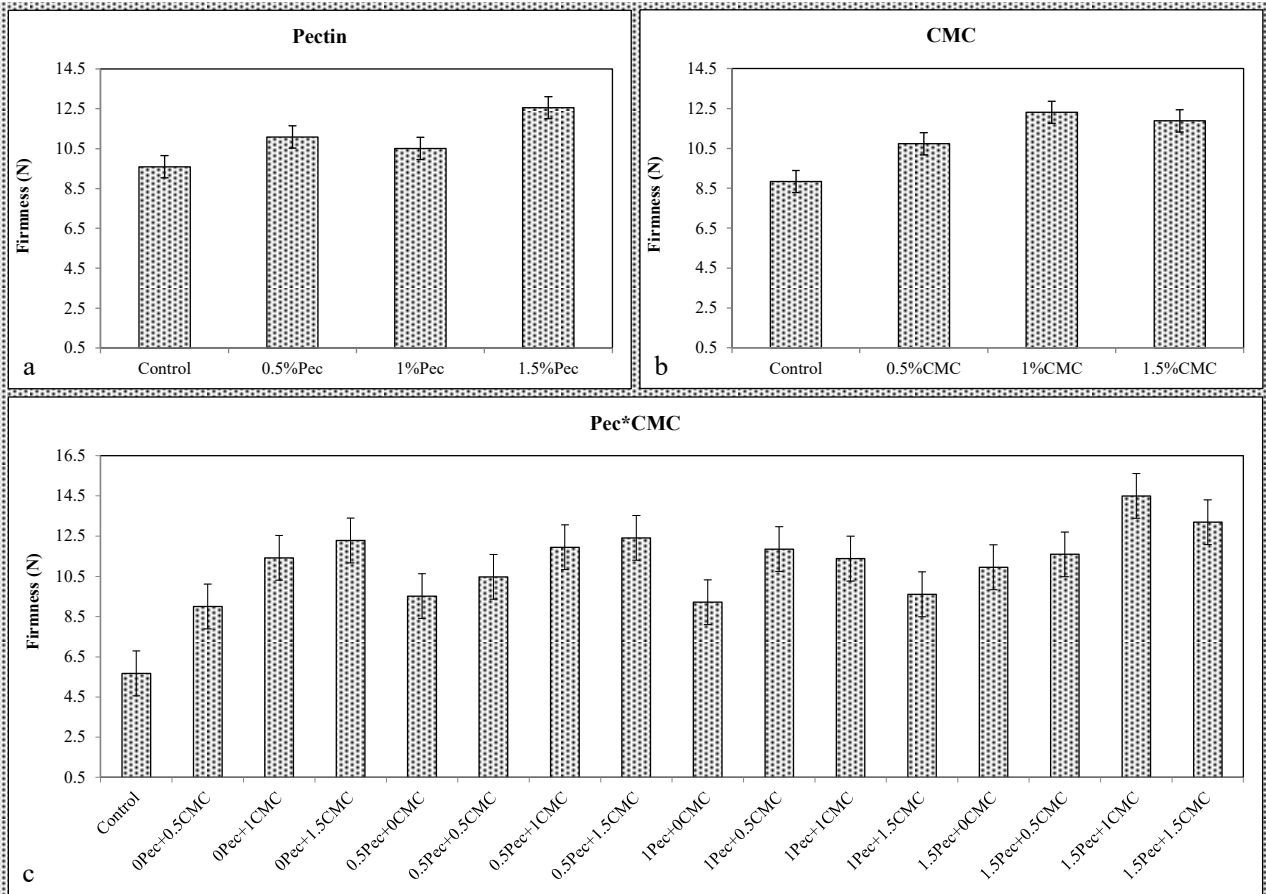

Figure 2. Effect of 0 (control), $0.5(0.5 \% \mathrm{Pec}), 1(1 \% \mathrm{Pec})$ and $1.5(1.5 \% \mathrm{Pec}) \%$ pectin-based edible coatings (a), 0 (control), 0.5 (0.5\% CMC), 1 (1\% CMC) and 1.5 (1.5\% CMC) \% carboxymethylcellulose-based edible coatings (b) and their combinations (c) on firmness during cold storage period. Data are the "estimated marginal means $\pm 95 \%$ confidence intervals". The columns with non-overlapping error bars are significantly different $(p \leq 0.05)$. 
Pec coating at $1 \%$ and $\mathrm{CMC}$ at $0.5 \%$ significantly increased vit $\mathrm{C}$ concentration compared to control samples (Figure 3a,b). Among Pec ${ }^{*} \mathrm{CMC}$ combinations, 1.5\% Pec $+1.5 \% \mathrm{CMC}, 1 \% \mathrm{Pec}+0.5 \% \mathrm{CMC}$ and $1 \%$ Pec $+1 \%$ CMC showed higher levels of vit $C$ content (Figure $3 c$ ). The results suggest that coatings application, either alone or in combination, preserved vit $C$ content during storage.
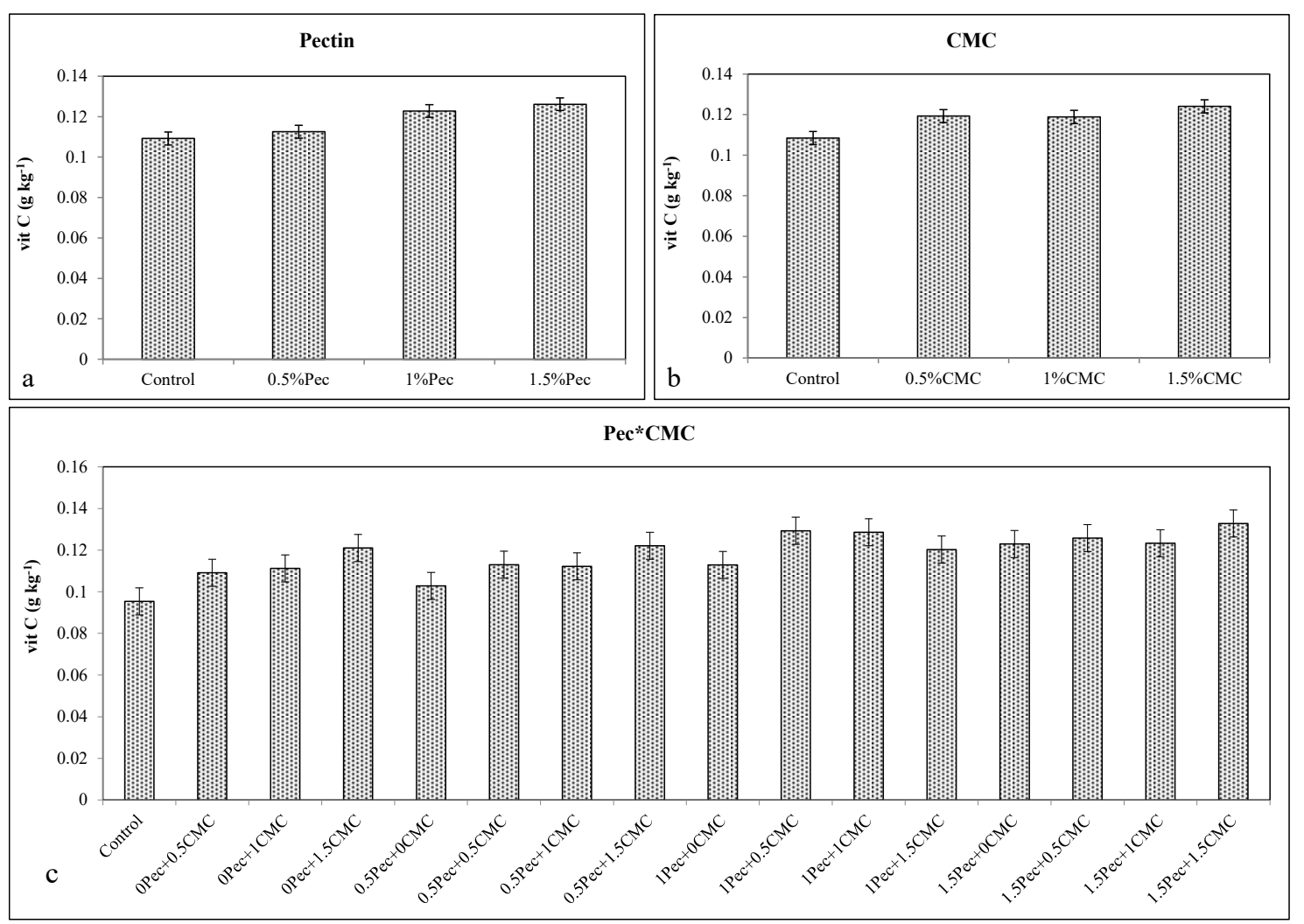

Figure 3. Effect of 0 (control), $0.5(0.5 \% \mathrm{Pec}), 1(1 \% \mathrm{Pec})$ and $1.5(1.5 \% \mathrm{Pec}) \%$ pectin-based edible coatings (a), 0 (control), 0.5 (0.5\% CMC), 1 (1\% CMC) and 1.5 (1.5\% CMC) \% carboxymethylcellulose-based edible coatings (b) and their combinations (c) on vitamin C (vit C) contents during cold storage period. Data are the "estimated marginal means $\pm 95 \%$ confidence intervals". The results were expressed on a fresh weight basis. The columns with non-overlapping error bars are significantly different $(p \leq 0.05)$.

The results for TSS values revealed that all Pec concentrations with the best result at $1.5 \%$ Pec $(\approx 9.731 \%)$ (Figure $4 a$ ), all CMC concentrations (Figure $4 b)$ and their combination at $0.5 \% \mathrm{Pec}+1.5 \%$ CMC $(\approx 9.443 \%)$ (Figure 4 c) significantly $(p \leq 0.01)$ reduced TSS of plum, as a positive result showing a lower breakdown in the fruit.

The $\mathrm{pH}$ values remained more or less stable in plum fruits coated with Pec (Figure 5a), CMC (Figure $5 b$ ) or their combinations (Figure $5 c$ ).

Weight loss of control fruits were around $15 \%$. No considerable difference was detected between the control and coated fruit (CMC, Pec and $\mathrm{Pec}^{*} \mathrm{CMC}$ ) in weight loss parameter (data not shown). 


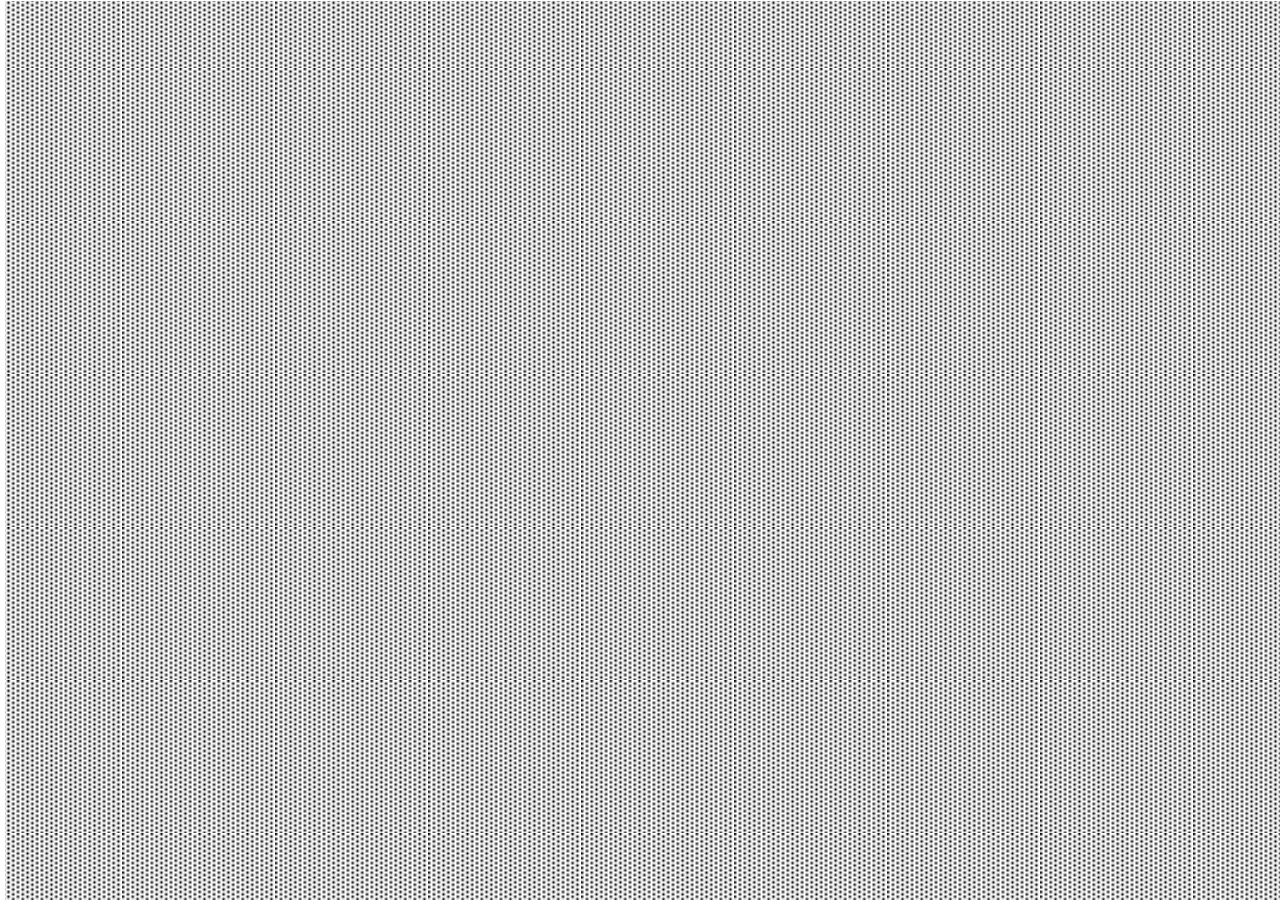

Figure 4. Effect of 0 (control), $0.5(0.5 \% \mathrm{Pec}), 1(1 \% \mathrm{Pec})$ and $1.5(1.5 \% \mathrm{Pec}) \%$ pectin-based edible coatings (a), 0 (control), 0.5 (0.5\% CMC), 1 (1\% CMC) and 1.5 (1.5\% CMC) \% carboxymethylcellulose-based edible coatings (b) and their combinations (c) on total soluble solids (TSS) contents during cold storage period. Data are the "estimated marginal means $\pm 95 \%$ confidence intervals". The results were expressed on a fresh weight basis. The columns with non-overlapping error bars are significantly different $(p \leq 0.05)$.
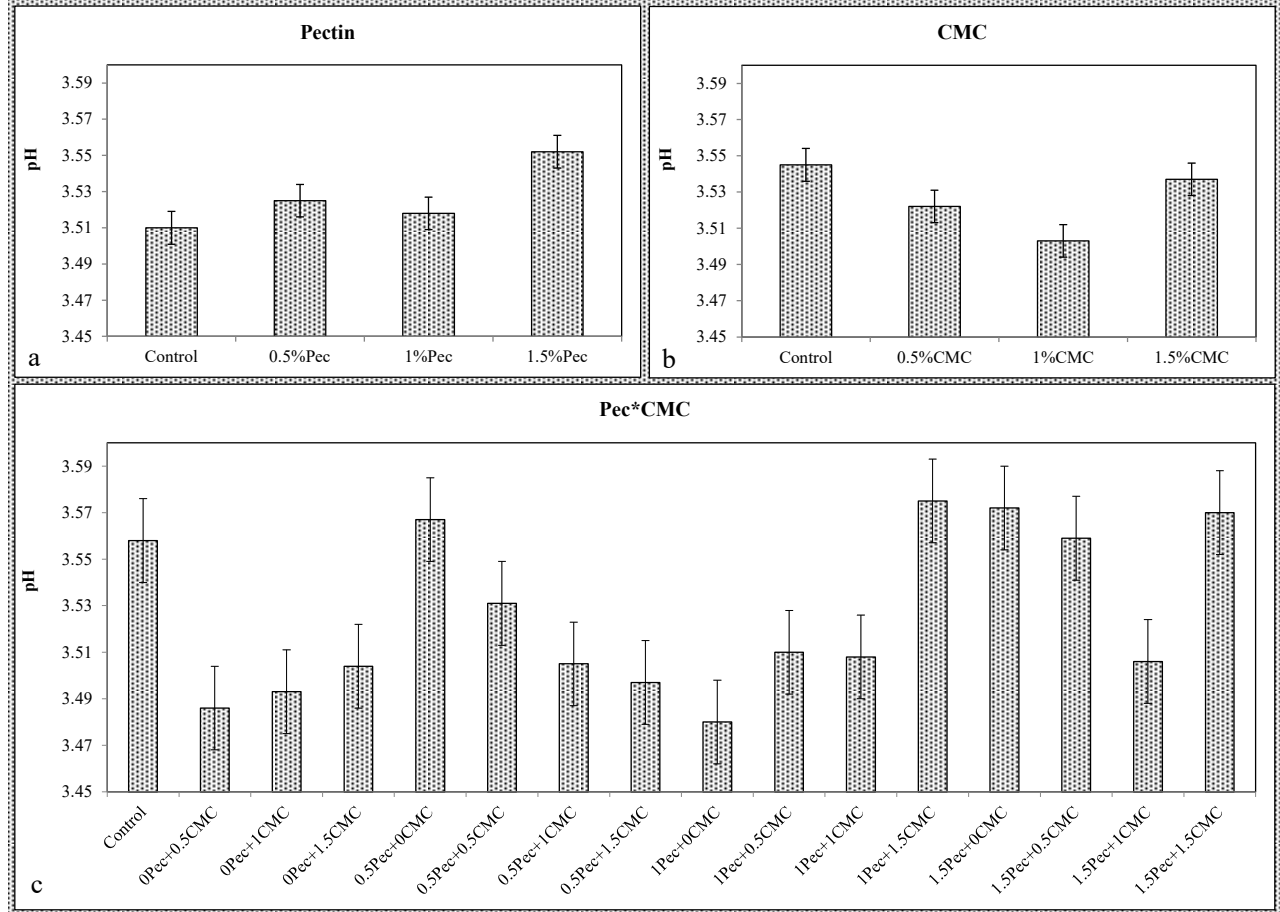

Figure 5. Effect of 0 (control), $0.5(0.5 \% \mathrm{Pec}), 1(1 \% \mathrm{Pec})$ and $1.5(1.5 \% \mathrm{Pec}) \%$ pectin-based edible coatings (a), 0 (control), 0.5 (0.5\% CMC), 1 (1\% CMC) and 1.5 (1.5\% CMC) \% carboxymethylcellulose-based edible coatings (b) and their combinations (c) on $\mathrm{pH}$ during cold storage period. Data are the "estimated marginal means $\pm 95 \%$ confidence intervals". The columns with non-overlapping error bars are significantly different $(p \leq 0.05)$. 


\subsection{Total Phenolic Compounds, Total Anthocyanin and Flavonoid Contents and Total Antioxidant Activity}

The increase in total phenols, anthocyanins, and flavonoids after the coatings application (Pec or CMC alone or selected combinations) is in agreement with higher antioxidant activity detected in all coated fruits. Coating at $0.5 \%$ Pec increased total phenols ( $\approx 0.989 \mathrm{~g} \mathrm{~kg}^{-1}$ gallic acid) (Figure 6a), anthocyanins $\left(\approx 0.5 \mathrm{~A}_{530} \mathrm{~g}^{-1}\right)$ (Figure $\left.7 \mathrm{a}\right)$, flavonoids $\left(\approx 2.02 \mathrm{~g} \mathrm{~kg}^{-1}\right.$ quercetin) (Figure 8a) and the antioxidant activity $(\approx 14.31 \%$ ) (Figure $9 \mathrm{a})$. Likewise, the application of $0.5 \% \mathrm{CMC}$ increased total phenols $\left(\approx 0.954 \mathrm{~g} \mathrm{~kg}^{-1}\right.$ gallic acid) (Figure $\left.6 \mathrm{~b}\right)$, anthocyanins $\left(\approx 0.467 \mathrm{~A}_{530} \mathrm{~g}^{-1}\right)$ (Figure $7 \mathrm{~b}$ ), flavonoids $\left(\approx 2.04 \mathrm{~g} \mathrm{~kg}^{-1}\right.$ quercetin) (Figure $\left.8 \mathrm{~b}\right)$ and the antioxidant activity $(\approx 14.3 \%)$ (Figure $\left.9 \mathrm{~b}\right)$. Their combination $(0.5 \% \mathrm{Pec}+0.5 \% \mathrm{CMC})$ resulted in higher total phenols $\left(\approx 0.976 \mathrm{~g} \mathrm{~kg}^{-1}\right.$ gallic acid) (Figure $\left.6 \mathrm{c}\right)$, anthocyanins $\left(\approx 0.515 \mathrm{~A}_{530} \mathrm{~g}^{-1}\right.$ ) (Figure $7 \mathrm{c}$ ), flavonoids $\left(\approx 2.07 \mathrm{~g} \mathrm{~kg}^{-1}\right.$ quercetin) (Figure $8 \mathrm{c}$ ) and antioxidant activity $(\approx 13.2 \%$ ) (Figure $9 \mathrm{c}$ ) than control samples. However, the highest values of total phenolic compounds $\left(\approx 0.976 \mathrm{~g} \mathrm{~kg}^{-1}\right.$ gallic acid) (Figure $\left.6 \mathrm{c}\right)$, anthocyanins $\left(\approx 0.543 \mathrm{~A}_{530} \mathrm{~g}^{-1}\right)$ (Figure $7 \mathrm{c}$ ), flavonoids $\left(\approx 2.07 \mathrm{~g} \mathrm{~kg}^{-1}\right.$ quercetin) (Figure $8 \mathrm{c}$ ) and antioxidant activity $(\approx 21.6 \%)$ (Figure 9c) were achieved by the combinations $0.5 \% \mathrm{Pec}+0.5 \% \mathrm{CMC}, 0.5 \% \mathrm{Pec}+1 \% \mathrm{CMC}, 0.5 \% \mathrm{Pec}+0.5 \% \mathrm{CMC}$ and $1.5 \%$ Pec $+1 \%$ CMC, respectively.
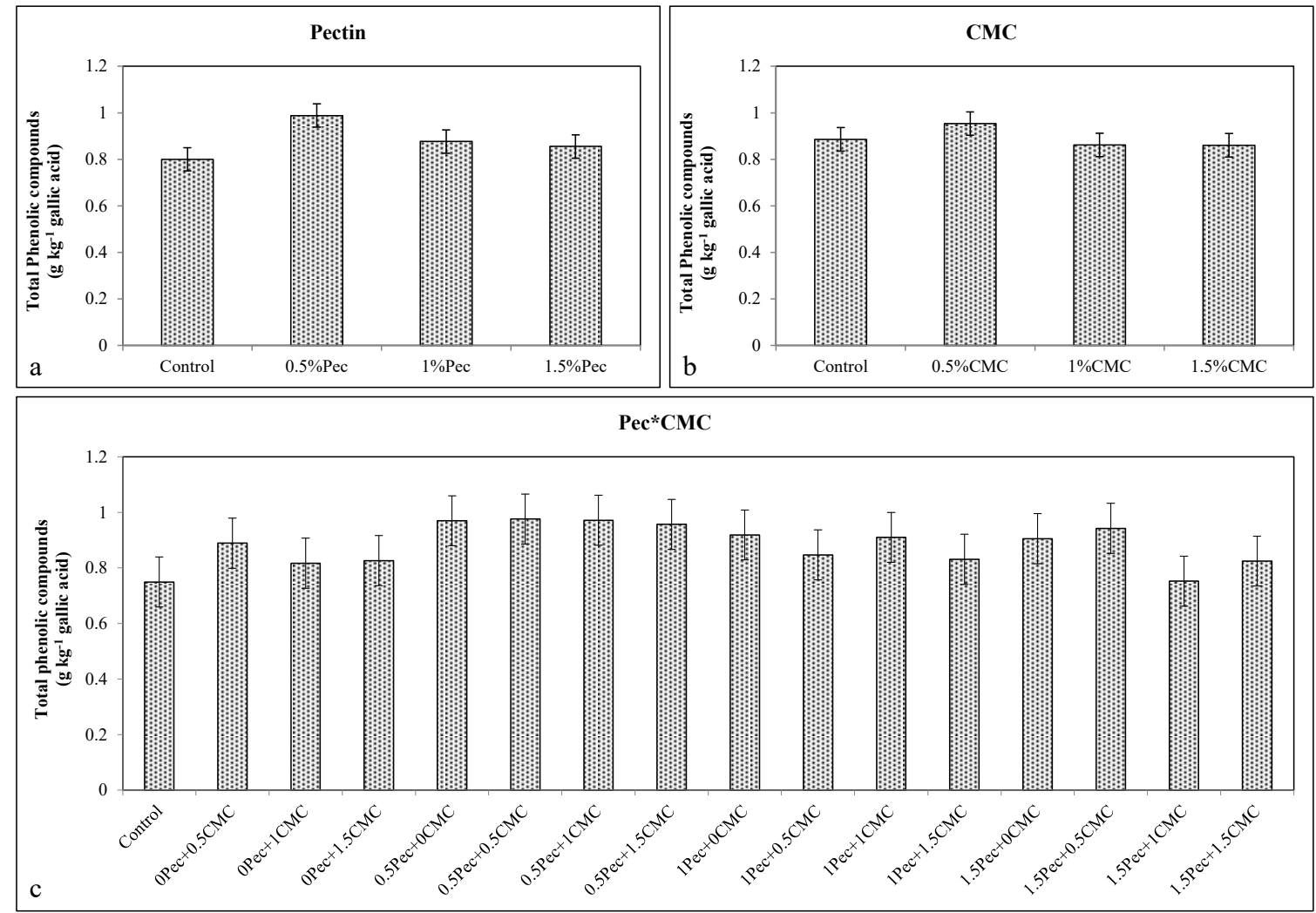

Figure 6. Effect of 0 (control), $0.5(0.5 \%$ Pec $), 1(1 \%$ Pec $)$ and $1.5(1.5 \%$ Pec $) \%$ pectin-based edible coatings (a), 0 (control), 0.5 (0.5\% CMC), 1 (1\% CMC) and 1.5 (1.5\% CMC) \% carboxymethylcellulose-based edible coatings (b) and their combinations (c) on total phenolic compounds during cold storage period. Data are the "estimated marginal means $\pm 95 \%$ confidence intervals". The results were expressed on a fresh weight basis. The columns with non-overlapping error bars are significantly different $(p \leq 0.05)$. 

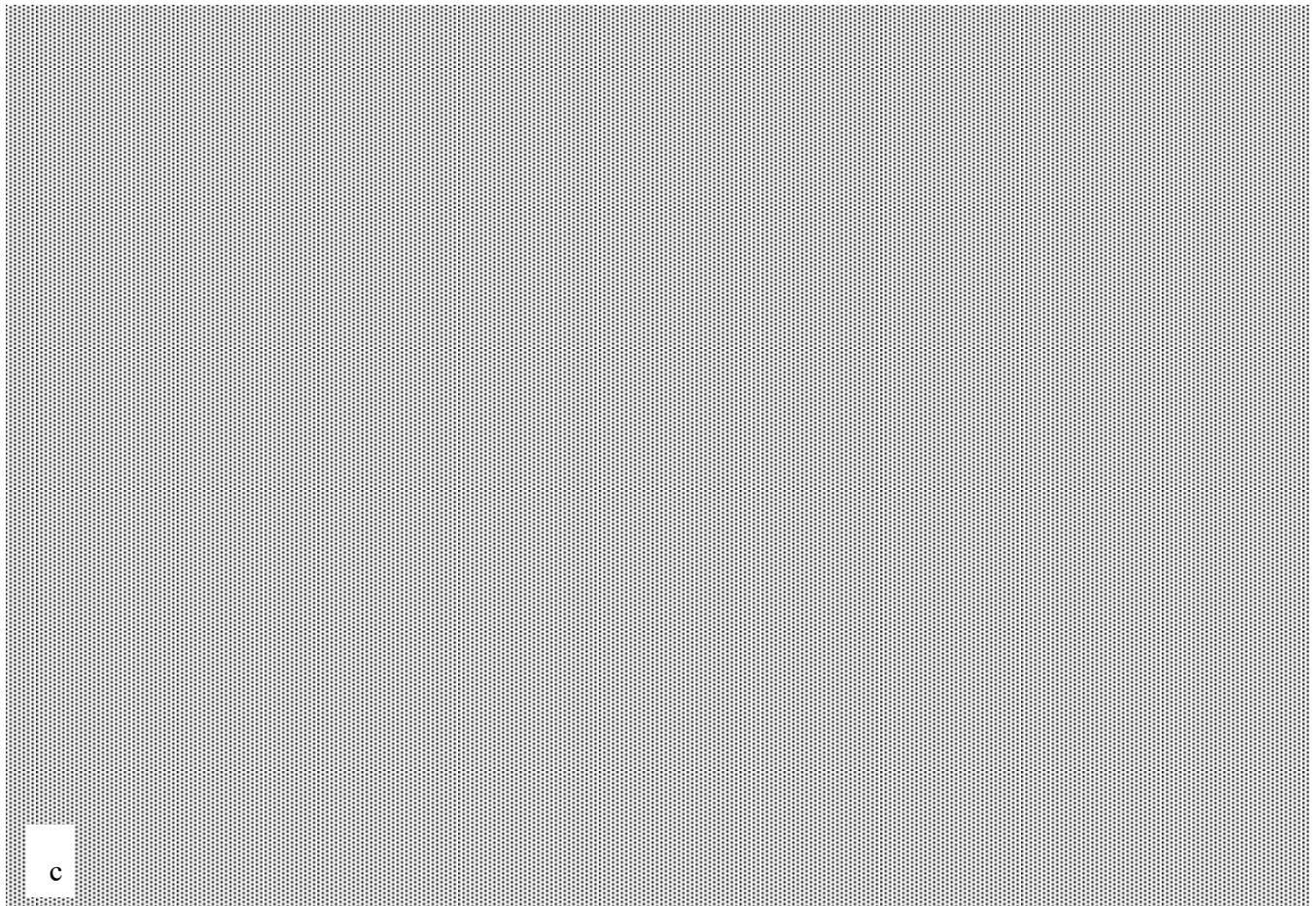

Figure 7. Effect of 0 (control), $0.5(0.5 \%$ Pec $), 1(1 \%$ Pec) and $1.5(1.5 \%$ Pec $) \%$ pectin-based edible coatings (a), 0 (control), 0.5 (0.5\% CMC), 1 (1\% CMC) and 1.5 (1.5\% CMC) \% carboxymethylcellulose-based edible coatings (b) and their combinations (c) on anthocyanin during cold storage period. Data are the "estimated marginal means $\pm 95 \%$ confidence intervals". The results were expressed on a fresh weight basis. The columns with non-overlapping error bars are significantly different $(p \leq 0.05)$.

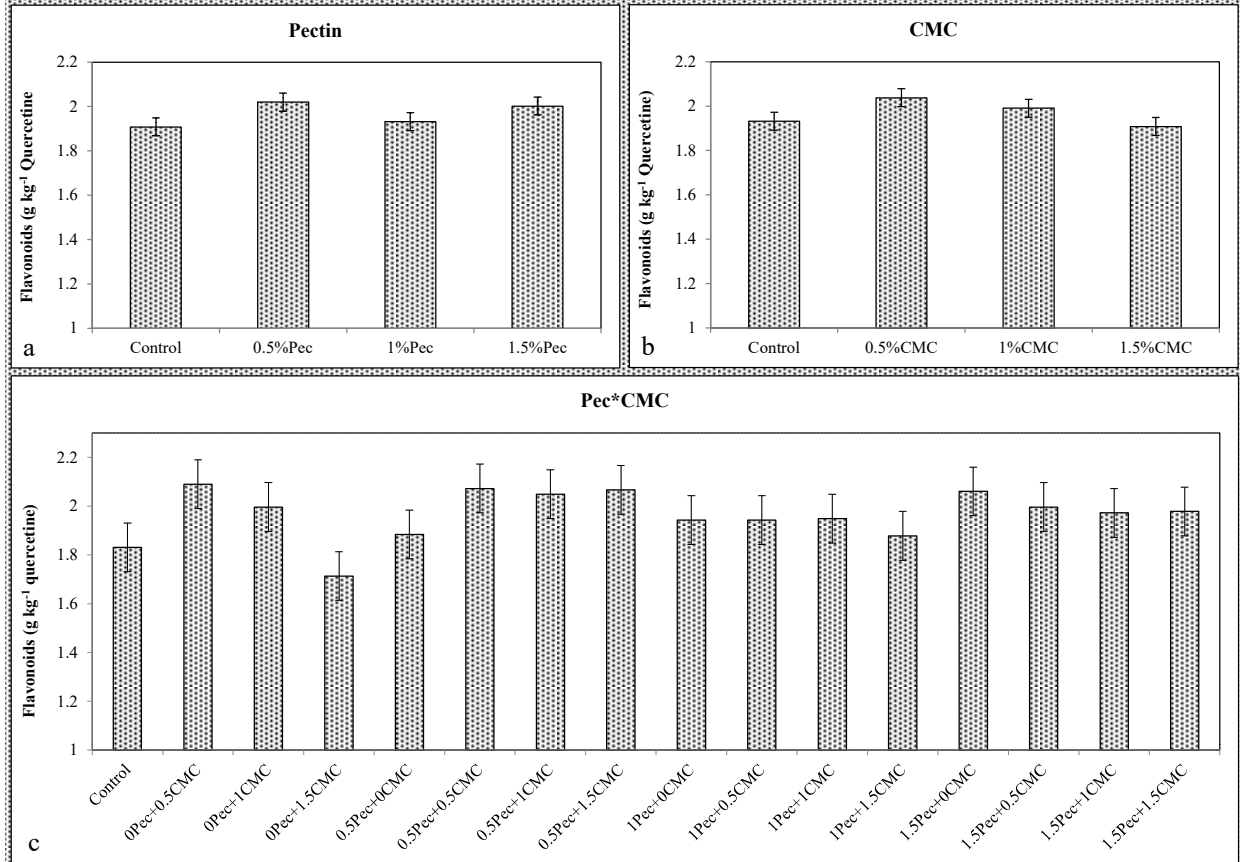

Figure 8. Effect of 0 (control), $0.5(0.5 \% \mathrm{Pec}), 1(1 \% \mathrm{Pec})$ and $1.5(1.5 \% \mathrm{Pec}) \%$ pectin-based edible coatings (a), 0 (control), 0.5 (0.5\% CMC), 1 (1\% CMC) and 1.5 (1.5\% CMC) \% carboxymethylcellulose-based edible coatings (b) and their combinations (c) on flavonoids contents during cold storage period. Data are the "estimated marginal means $\pm 95 \%$ confidence intervals". The results were expressed on a fresh weight basis. The columns with non-overlapping error bars are significantly different $(p \leq 0.05)$. 

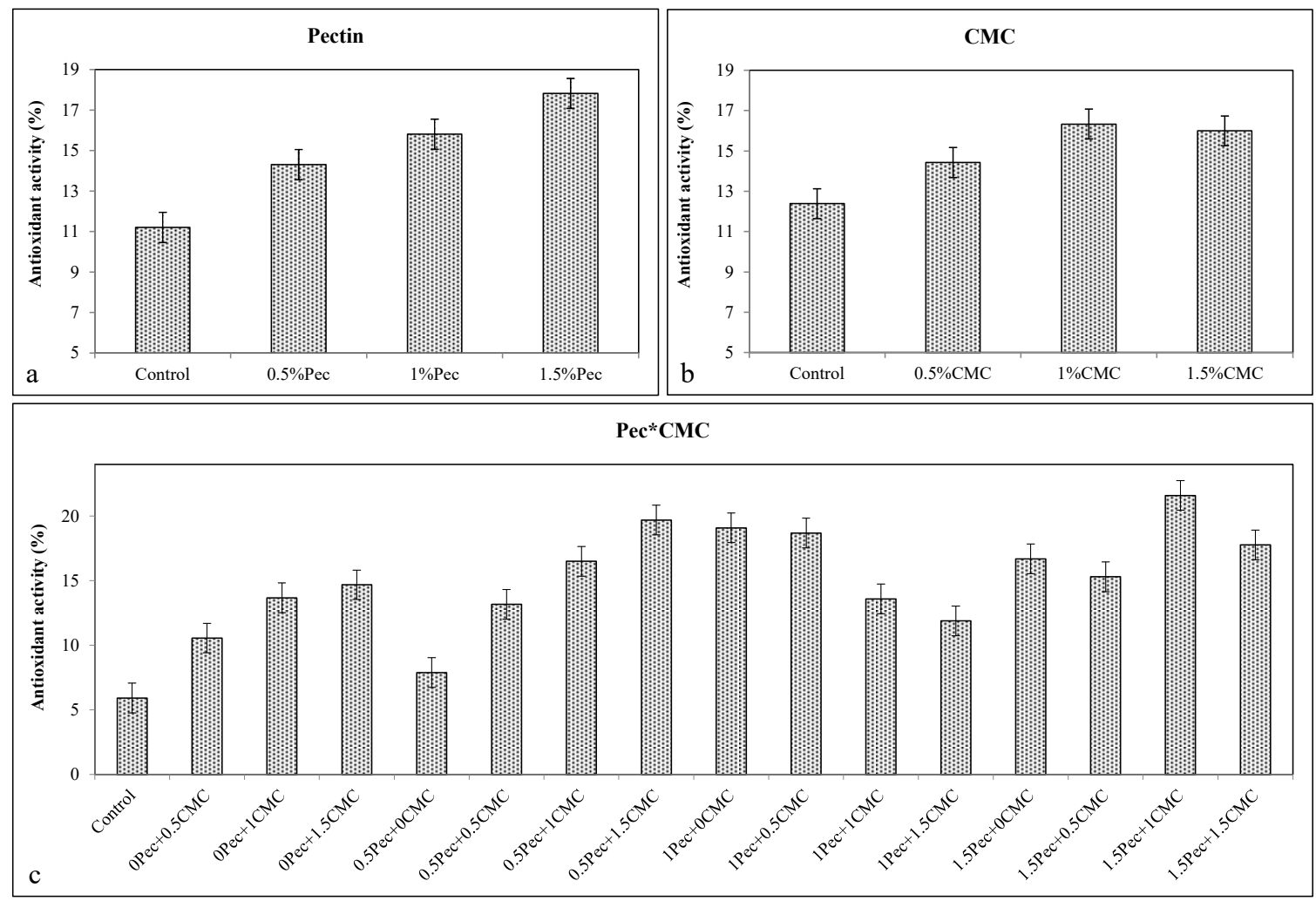

Figure 9. Effect of 0 (control), $0.5(0.5 \% \mathrm{Pec}), 1(1 \% \mathrm{Pec})$ and $1.5(1.5 \% \mathrm{Pec}) \%$ pectin-based edible coatings (a), 0 (control), 0.5 (0.5\% CMC), 1 (1\% CMC) and 1.5 (1.5\% CMC) \% carboxymethylcellulose-based edible coatings (b) and their combinations (c) on antioxidant activity based on the 1,1-Diphenyl-2-picrylhydrazyl hydrate (DPPH) method during cold storage period. Data are the "estimated marginal means $\pm 95 \%$ confidence intervals". The columns with non-overlapping error bars are significantly different $(p \leq 0.05)$.

\subsection{POD, PPO and PG Enzymes Activities}

Edible coatings determined higher POD activities compared to the control, with the maximum activity at $1 \%$ Pec concentration $\left(\approx 0.086 \mu \mathrm{mol}\right.$ tetraguaiacol $\mathrm{min}^{-1} \mathrm{~g}^{-1}$ ) (Figure $10 \mathrm{a}$ ) and $1.5 \% \mathrm{CMC}$ concentration $\left(\approx 0.082 \mu \mathrm{mol}\right.$ tetraguaiacol $\left.\mathrm{min}^{-1} \mathrm{~g}^{-1}\right)$ (Figure 10b). All combinations caused higher POD activities than the control $(\approx 0.076)$ with the highest activities at $1 \% \mathrm{Pec}+0.5 \% \mathrm{CMC}(\approx 0.129 \mu \mathrm{mol}$ tetraguaiacol $\left.\mathrm{min}^{-1} \mathrm{~g}^{-1}\right)$ and $1.5 \% \mathrm{Pec}+1.5 \% \mathrm{CMC}\left(\approx 0.104 \mu \mathrm{mol}\right.$ tetraguaiacol $\left.\mathrm{min}^{-1} \mathrm{~g}^{-1}\right)$ (Figure 10c).

Conversely, edible coatings significantly reduced PPO activity with the lowest values obtained with $1.5 \%$ Pec $\left(\approx 0.014 \mu \mathrm{mol}\right.$ oxidized catechol $\left.\mathrm{min}^{-1} \mathrm{~g}^{-1}\right)$ (Figure 11a), $1 \% \mathrm{CMC}(\approx 0.0137 \mu$ mol oxidized catechol $\left.\mathrm{min}^{-1} \mathrm{~g}^{-1}\right)$ (Figure 11b), and 1.5\% Pec $+1.5 \%$ CMC $\left(\approx 0.013 \mu\right.$ mol oxidized catechol $\left.\mathrm{min}^{-1} \mathrm{~g}^{-1}\right)$ (Figure 11c). A similar effect was found for the PG activity. In this case, the lowest enzymatic activity was achieved after the application of $0.5 \%$ and $1.5 \%$ Pec $\left(\approx 0.718 \mu \mathrm{mol}\right.$ D-galacturonic acid $\left.\mathrm{min}^{-1} \mathrm{~g}^{-1}\right)$ (Figure 12a), 0.5\%-1.5\% CMC ( $\approx 0.725 \mu \mathrm{mol}$ D-galacturonic acid $\mathrm{min}^{-1} \mathrm{~g}^{-1}$ ) (Figure $12 \mathrm{~b}$ ), and $0.5 \% \mathrm{Pec}$ $+1 \% \mathrm{CMC}\left(\approx 0.696 \mu \mathrm{mol}\right.$ D-galacturonic acid $\left.\mathrm{min}^{-1} \mathrm{~g}^{-1}\right)$ (Figure 12c). 

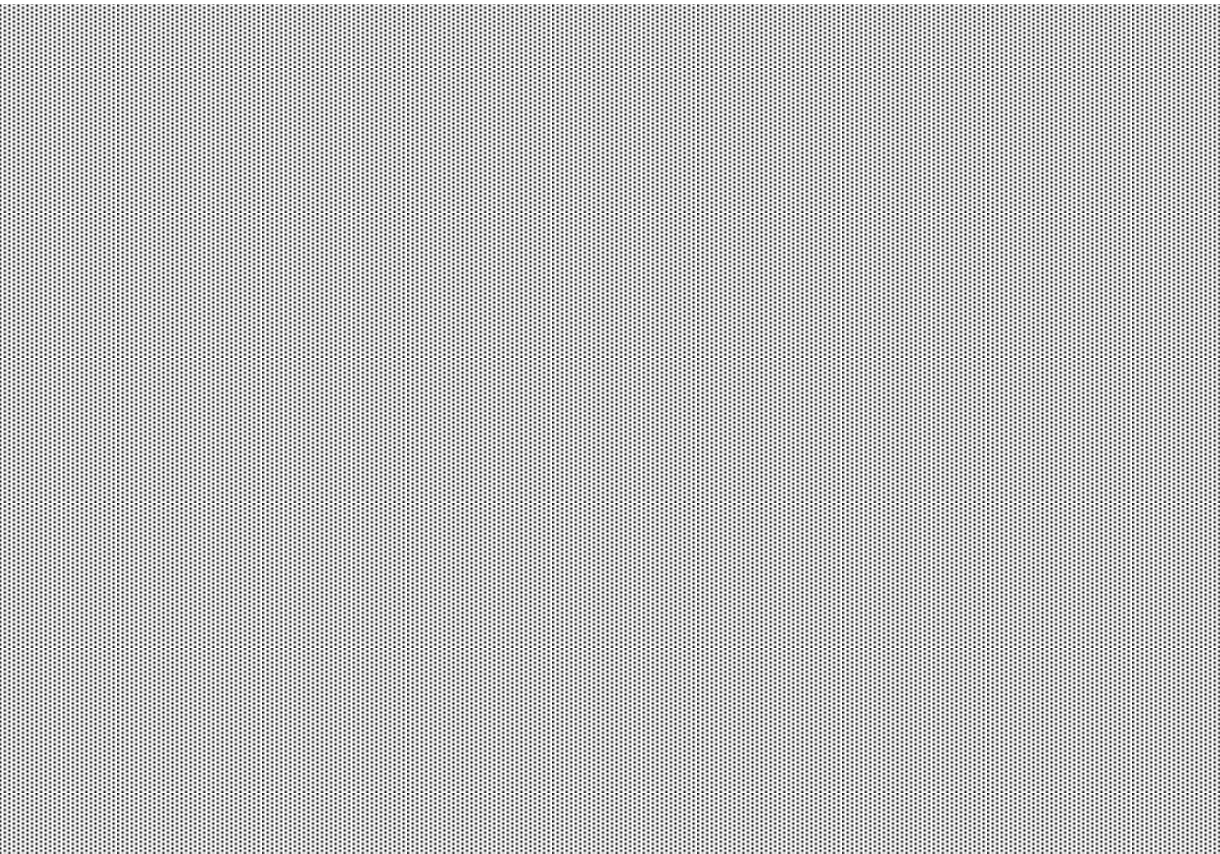

Figure 10. Effect of 0 (control), $0.5(0.5 \% \mathrm{Pec}), 1(1 \% \mathrm{Pec})$ and $1.5(1.5 \% \mathrm{Pec}) \%$ pectin-based edible coatings $(\mathbf{a})$, 0 (control), 0.5 (0.5\% CMC), 1 (1\% CMC) and 1.5 (1.5\% CMC) \% carboxymethylcellulose-based edible coatings (b) and their combinations (c) on peroxidase (POD) enzyme activity during cold storage period. Data are the "estimated marginal means $\pm 95 \%$ confidence intervals". The results were expressed on a fresh weight basis. The columns with non-overlapping error bars are significantly different $(p \leq 0.05)$.
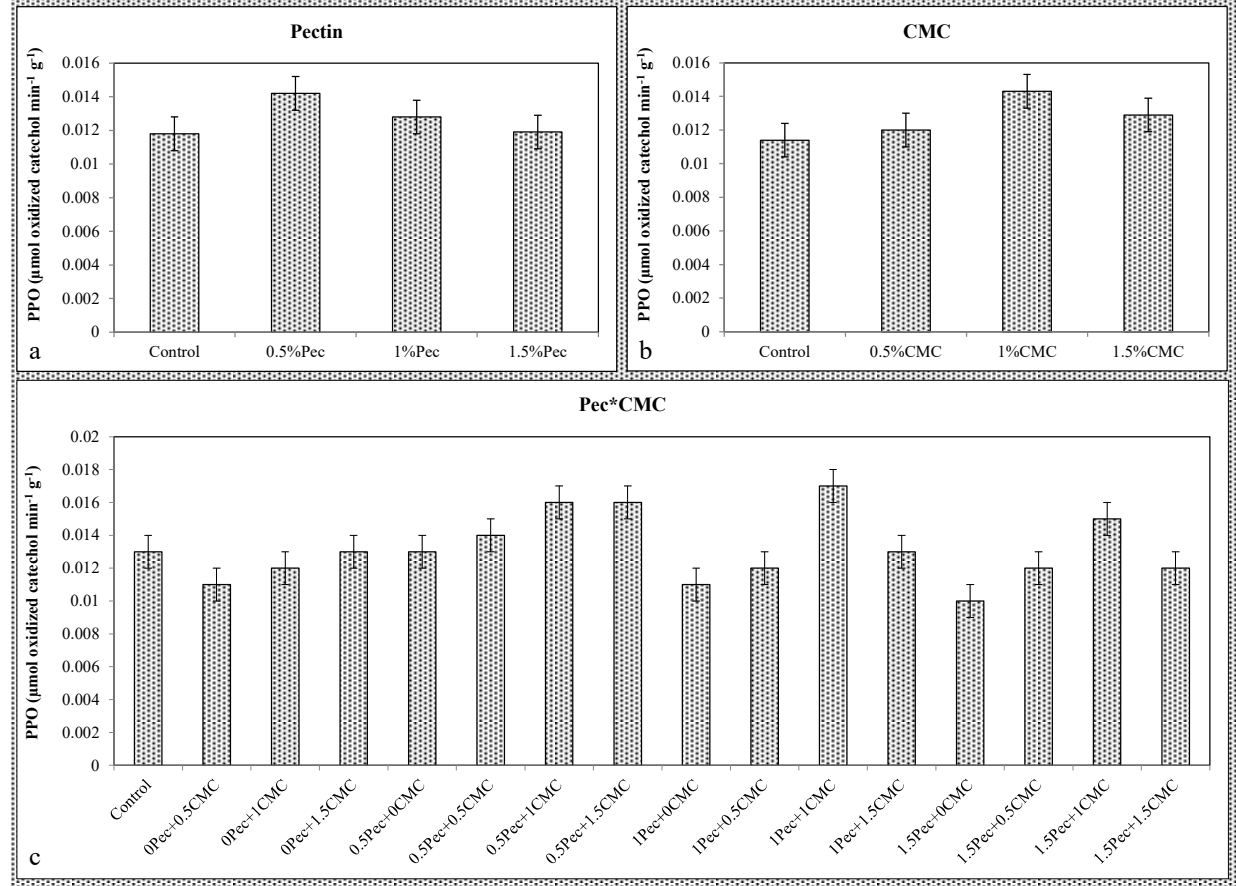

Figure 11. Effect of 0 (control), $0.5(0.5 \% \mathrm{Pec}), 1(1 \% \mathrm{Pec})$ and $1.5(1.5 \% \mathrm{Pec}) \%$ pectin-based edible coatings $(\mathbf{a})$, 0 (control), 0.5 (0.5\% CMC), 1 (1\% CMC) and 1.5 (1.5\% CMC) \% carboxymethylcellulose-based edible coatings (b) and their combinations (c) on polyphenol oxidase (PPO) enzyme activity during cold storage period. Data are the "estimated marginal means $\pm 95 \%$ confidence intervals". The results were expressed on a fresh weight basis. The columns with non-overlapping error bars are significantly different $(p \leq 0.05)$. 

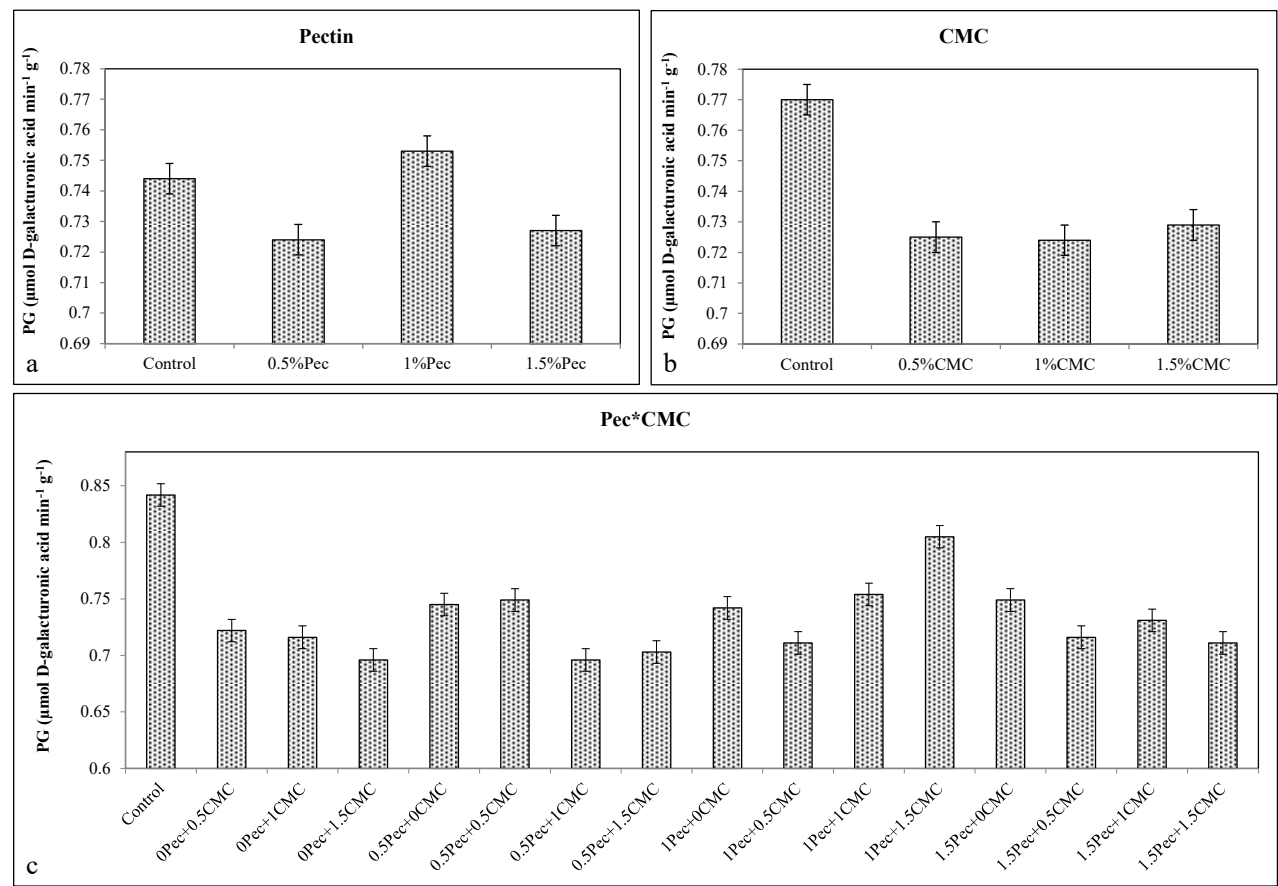

Figure 12. Effect of 0 (control), $0.5(0.5 \%$ Pec $), 1(1 \%$ Pec $)$ and $1.5(1.5 \%$ Pec $) \%$ pectin-based edible coatings $(\mathbf{a})$, 0 (control), 0.5 (0.5\% CMC), 1 (1\% CMC) and 1.5 (1.5\% CMC) \% carboxymethylcellulose-based edible coatings (b) and their combinations (c) on polygalacturonase (PG) enzyme activity during cold storage period. Data are the "estimated marginal means $\pm 95 \%$ confidence intervals". The results were expressed on a fresh weight basis. The columns with non-overlapping error bars are significantly different $(p \leq 0.05)$.

\section{Discussion}

The obtained results demonstrated 1\% CMC, 1.5\% Pec and $0.5 \% \mathrm{Pec}+1.5 \% \mathrm{CMC}$ as the best treatments for the preservation of the nutritional value of plums during postharvest cold storage.

In general, degradation of organic acids into sugars through respiration process decreases TA during postharvest [16,32]. Moreover, utilization of organic acids as a carbon skeleton for synthesizing new compounds could be another reason for TA reduction [16]. Delay in fruit ripening [5] and maturation [33] caused by coating might reduce respiratory metabolisms involved in TA loss. Positive effects of coatings on TA maintenance have been previously reported [24,34]. The $1 \%$ CMC treatment could prevent TA loss of plum during shelf life [8]. However, in the current study, all CMC concentrations increased TA value almost in line with Panahirad et al. [8].

Decrease in cell wall enzymes activities might be a probable reason for firmness preservation as stated by Sanchis et al. [23] and Kumar et al. [24] due to ripening delay by coating application [6]. Polygalacturonase (PG) enzyme is one of the main softening enzymes in plum [35]. Reduction in PG activity after coating (Figure 12) also reflects importance of this enzyme in plum softening. PG activity relies on respiration and production of ethylene. Therefore, unavailability of $\mathrm{O}_{2}$ postpones biosynthesis of ethylene and later textural changes in coated fruit. Consequently, controlling $\mathrm{O}_{2}$ availability and modifying internal gas composition by edible coatings decrease oxidative metabolism and delay changes in the fruit texture $[33,36]$. This can be another possible reason for firmness preservation here observed. The existence of carboxylic groups in chemical structure of CMC may cause a positive effect on firmness preservation [18]. The reduction of the soluble pectin fractions might be another reason for this positive effect $[6,16]$. Positive effect of CMC- and Pec-based edible coatings on firmness preservation has been previously reported [8,34]. Martinez-Romero et al. [37] and Kumar et al. [38] also reported positive effects of rosehip oil added to Aloe vera gel and lac-based coatings on plum firmness, respectively. 
Antioxidant activity of vit $C$ causes its loss during postharvest storage [6,19]. Ascorbic-acid oxidase and polyphenol oxidase modify vit $\mathrm{C}$ content whose activities directly rely on $\mathrm{O}_{2}$ availability. The decrease in the respiration rate [39] as well as the modulation of the $\mathrm{O}_{2}$ and $\mathrm{CO}_{2}$ transmission rate through the coating layer [32] could explain the vitamin C preservation. Indeed, Oms-Oliu et al. [40] reported that the coatings based on pectin produced a reduction of $\mathrm{O}_{2}$ diffusion and an increase in $\mathrm{CO}_{2}$ in the coated pears. The reduction of the PPO activity (Figure 11) in the coated samples could also be related with the vitamin $C$ preservation. Similar results were already reported $[24,34,36]$. The vit $C$ results of the current study are in agreement with our previous studies [8,41].

TSS is an important quality parameter and its amount at harvest as well as during storage is important for consumer acceptance [35]. The thin layer of the coating on the fruit surface reduces evaporation, delays degradation and reduces respiration rate which, in turn, might have a positive effect on the prevention of TSS during storage. Positive effect of different edible coatings on TSS has been previously reported $[24,32,34]$.

Some reports demonstrated that CMC- and Pec-based edible coatings could maintain a stable $\mathrm{pH}$ value $[17,32,34]$ in agreement with our current findings.

Phenolic content contributes directly to the total antioxidant activity [3,42]. The upsurge in phenolic, anthocyanin and flavonoid contents was associated with a reduced PPO activity in the coated fruits as PPO triggers the oxidation of phenolics and flavonoids and degradation of anthocyanins [27,39]. In the current study, the reduction in PPO activity in the coated plums could be an explanation for the increase in phenolics, anthocyanins and flavonoids content. Pec-based edible coatings containing additives (such as anti-browning, apple fiber, and antioxidants) [20,40], as well as CMC [17] led to the accumulation of phenolic compounds. A positive effect of different coatings (alone or in combination with additives) on total phenolics has been reported [22,24,36,43]. Panahirad et al. [8] reported a negative effect of CMC on total phenolics, and a positive effect on anthocyanins and flavonoids contents. Pec-based edible coating enhanced phenolics, anthocyanins and flavonoids of plum and decreased PPO [41]. Chitosan coating caused higher quantities of phenolic compounds, anthocyanins and flavonoids [44] and a decline in the activity of PPO [27,45]. Other authors [20,22] reported higher flavonoid concentrations in the fruits treated with Pec-cinnamon leaf oil- and sodium alginate/Pec-based coatings, respectively.

The vit $C$ has also antioxidative properties, however phenolic compounds along with anthocyanins and flavonoids are the main radical scavenging molecules [3,35,42]. The increase in the concentration of the mentioned compounds is in agreement with the enhancement of the total antioxidant activity and enzymatic activity of POD, a well-known antioxidant enzyme $[27,39,46]$. The enhancement of the total phenol content, anthocyanins, flavonoids, as well as the vit $C$ preservation, the lower PPO activity, the higher POD activity, and the lower O2 permeability can all contribute, to different extents, to the higher antioxidant activity of the coated fruits. The increasing trend using the DPPH method in plum fruit during storage was previously reported $[8,38,41,47]$. The enhancement of antioxidant activity was also noticed in apple pieces coated with pectin in combination with pulse light treatment [48]. Oms-Oliu et al. [40] and Ayala-Zavala et al. [20] described similar positive effects using DPPH method on Pec-coated fruits. Guerriero et al. [22], Kumar et al. [24] and Ali et al. [49] all reported the preservation or the increase in the antioxidant activities of the fruits treated with sodium alginate/Pec-, chitosan- and gum Arabic-based coatings, respectively.

POD activity enhancement after application of Pec and CMC coatings has been reported by Ramirez et al. [21] and Panahirad et al. [8] in nectarine and plum, respectively. Panahirad et al. [41] additionally reported enhancement in POD activity on Pec-coated plums. Enhancement in POD activity could reduce the level of harmful radicals and consequently improves the antioxidant activity and postharvest quality of fruit maintaining their nutritional value. The positive effect of the applied coatings might be referred to formation of a semi-permeable barrier on fruit surface that restricts gas exchange and reduces water loss. This property delays physiological and biochemical changes that could result in quality preservation and strengthening of the antioxidant defense. In fact, slowing 
down the metabolic processes involved in senescence, ripening and decay might be considered as the main reason for POD enzyme enhancement by the applied coatings.

High PPO activity and phenolics oxidation are observed during storage, due to senescence-related processes, especially the destruction of biological barriers between PPO and polyphenols that activates the enzyme [19]. The application of coatings modulates the $\mathrm{O}_{2}$ exposure, decreasing the PPO activity $[23,39]$. In addition, reduction in $\mathrm{pH}$ can decrease the enzyme activity [23]. Decline in PPO activity by different coatings such as CMC, Pec, and chitosan has been previously reported $[8,23,27,41,45]$. Storage improvement by decreasing $\mathrm{O}_{2}$ availability, preservation of cellular compartmentation, protecting membrane structure from peroxidation and $\mathrm{pH}$ reduction due to slowing down of senescence and delaying of softening can be considered as possible reasons for the lower PPO activity.

\section{Conclusions}

The current survey reported positive effects of CMC- and Pec-based edible coatings, either alone or in combination with each other, on plum fruit through cold storage in terms of the measured parameters, except weight loss. The coatings especially improved vit $C$, total phenolics, anthocyanins and flavonoids contents and POD enzyme activity and decreased PPO and PG enzymes activities. $\mathrm{CMC}$ at $1 \%$ and Pec at $1.5 \%$ demonstrated the best results. Additionally, $0.5 \% \mathrm{Pec}+1.5 \% \mathrm{CMC}$ is a good combined formulation for the preservation of the nutritional value of plum during postharvest. Thus, application of CMC and/or Pec and/or their combinations might be considered as a favorable and safe coating approach for extending and improving postharvest qualitative characteristics of plum fruit.

Author Contributions: N.M. and R.N.-H. and S.P. designed the experiment. S.P. performed the work and wrote the first draft of the manuscript. N.M. and S.P. analyzed data. N.M. supervised the overall work and reviewed and edited the manuscript. R.N.-H., S.B. and R.K. read the manuscript, gave valuable comments and improved its quality. All authors have read and agreed to the published version of the manuscript.

Funding: Part of this work received funding from the University of Tabriz towards Ph.D. thesis for S.P. which is being acknowledged. In addition, R.K. acknowledges the support from the National Science Foundation REU grant number 1560049.

Conflicts of Interest: Submitted work was not carried out in the presence of any personal, professional, or financial relationships that could be potentially construed as a conflict of interest.

\section{References}

1. Cevallos-Casals, B.; Byrne, D.; Okie, W.R.; Cisneros-Zevallos, L. Selecting new peach and plum genotypes rich in phenolic compounds and enhanced functional properties. Food Chem. 2006, 96, 273-280. [CrossRef]

2. Wargovich, M.J. Anticancer properties of fruits and vegetables. HortScience 2000, 35, 573-575. [CrossRef]

3. Gil, M.; Tomas-Barberan, F.; Hess-Pierce, B.; Kader, A. Antioxidant capacities, phenolic compounds, carotenoids, and vitamin A contents of nectarine, peach and plum cultivars from California. J. Agric. Food Chem. 2002, 50, 4976-4982. [CrossRef] [PubMed]

4. Diaz-Mula, H.M.; Zapata, P.J.; Guillen, F.; Martınez-Romero, D.; Castillo, S.; Serrano, M.; Valero, D. Changes in hydrophilic and lipophilic antioxidant activity and relative bioactive compounds during postharvest storage of yellow and purple plum cultivars. Postharvest Biol. Technol. 2009, 51, 354-363. [CrossRef]

5. Eum, H.A.; Hwang, D.K.; Linke, M.; Lee, S.K.; Zude, M. Influence of edible coating on quality of plum (Prunus salicina Lindl. cv. 'Sapphire'). Eur. Food Res. Technol. 2009, 229, 427-434. [CrossRef]

6. Hussain, P.R.; Suradkar, P.P.; Wani, A.M.; Dar, M.A. Retention of storage quality and post-refrigeration shelf-life extension of plum (Prunus domestica L.) cv. Santa Rosa using combination of carboxymethyl cellulose (CMC) coating and gamma irradiation. Radiat. Phys. Chem. 2015, 107, 136-148. [CrossRef]

7. Hassan, B.; Chatha, S.A.S.; Hussain, A.I.; Zia, K.M.; Akhtar, M. Recent advances in polysaccharides, lipids and protein based edible films and coatings: A review. Int. J. Biol. Macromol. 2017, 109, 1095-1107. [CrossRef]

8. Panahirad, S.; Naghshiband-Hassani, R.; Ghanbarzadeh, B.; Zaare-Nahandi, F.; Mahna, N. Shelf life quality of plum fruits (Prunus domestica L.) improves with carboxymethylcellulose-based edible coating. HortScience 2019, 54, 505-510. [CrossRef] 
9. Mahajan, B.V.C.; Tandon, R.; Kapoor, S.; Sidhu, M.K. Natural coatings for shelf-life enhancement and quality maintenance of fresh fruits and vegetables-A review. J. Postharvest Technol. 2018, 6, 12-26.

10. Bifani, V.; Ramirez, C.; Ihl, M.; Rubilar, M.; Garcia, A.; Zaritzky, N. Effects of murta (Ugni molinae Turcz.) extract on gas and water vapor permeability of carboxymethylcellulose-based edible films. LWT 2007, 40, 1473-1481. [CrossRef]

11. Tongdeesoontorn, W.; Mauer, L.J.; Wongruong, S.; Sriburi, P.; Rachtanapun, P. Effect of carboxymethylcellulose concentration on physical properties of biodegradable cassava starch-based films. Chem. Cent. J. 2011, 5, 6. [CrossRef] [PubMed]

12. Jafarizadeh-Malmiri, H.; Osman, A.; Tan, C.P.; Abdul-Rahman, R. Development of an edible coating based on chitosan-glycerol to delay 'Berangan' banana (Musa sapientum cv. Berangan) ripening process. Int. Food Res. J. 2011, 18, 989-997.

13. Kohli, P.; Gupta, R. Alkaline pectinases: A review. Biocatal. Agric. Biotechnol. 2015, 4, 279-285. [CrossRef]

14. Valdes, A.; Burgos, N.; Jimenez, A.; Garrigos, M.C. Natural pectin polysaccharides as edible coatings. Coatings 2015, 5, 865-886. [CrossRef]

15. Ciolacu, L.; Nicolau, A.I.; Hoorfar, J. Global safety of fresh produce. In A Handbook of Best Practice, Innovative Commercial Solutions and Case Studies; Woodhead Publishing Limited: Sawston, UK, 2014.

16. Hussain, P.R.; Meena, R.S.; Dar, M.A.; Wani, A.M. Carboxymethyl Cellulose coating and low-dose gamma irradiation improves storage quality and shelf life of pear (Pyrus Communis L., cv. Bartlett/William). J. Food Sci. 2010, 75, M586-M596. [CrossRef] [PubMed]

17. Vyas, P.B.; Gol, N.B.; Rao, T.V.R. Postharvest quality maintenance of papaya fruit using polysaccharide-based edible coatings. Int. J. Fruit Sci. 2014, 14, 81-94. [CrossRef]

18. Arnon, H.; Granit, R.; Porat, R.; Poverenov, E. Development of polysaccharides-based edible coatings for citrus fruits: A layer-by-layer approach. Food Chem. 2015, 166, 465-472. [CrossRef]

19. Hussain, P.R.; Suradkar, P.P.; Wani, A.M.; Dar, M.A. Potential of carboxymethyl cellulose and $\gamma$-irradiation to maintain quality and control disease of peach fruit. Int. J. Biol. Macromol. 2016, 82, 114-126. [CrossRef]

20. Ayala-Zavala, J.F.; Silva-Espinoza, B.A.; Cruz-Valenzuela, M.R.; Leyva, J.M.; Ortega-Ramirez, L.A.; Carrazco-Lugo, D.K.; Perez-Carlon, J.J.; Melgarejo-Flores, B.G.; Gonzalez-Aguilar, G.A.; Miranda, M.R.A. Pectin-cinnamon leaf oil coatings add antioxidant and antibacterial properties to fresh-cut peach. Flavour. Fragr. J. 2013, 28, 39-45. [CrossRef]

21. Ramirez, M.E.; Timon, M.L.; Petron, M.J.; Andrés, A.I. Effect of chitosan, pectin and sodium caseinate edible coatings on shelf life of fresh-cut Prunus persica var. Nectarine. J. Food Process Preserv. 2015, 39, 2687-2697. [CrossRef]

22. Guerreiro, A.C.; Gago, C.M.L.; Faleiro, M.L.; Miguel, M.G.C.; Antunes, M.D.C. The effect of edible coatings on the nutritional quality of 'Bravo de Esmolfe' fresh-cut apple through shelf-life. LWT Food Sci. Technol. 2017, 75, 210-219. [CrossRef]

23. Sanchis, E.; Chidelli, C.; Sheth, C.C.; Mateos, M.; Palou, L.; Perez-Gago, M.B. Integration of antimicrobial pectin-based edible coating and active modified atmosphere packaging to preserve the quality and microbial safety of fresh-cut persimmon (Diospyros kaki Thunb. cv. Rojo Brillante). J. Sci. Food Agric. 2017, 97, 252-260. [CrossRef] [PubMed]

24. Kumar, P.; Sethi, S.; Sharma, R.R.; Srivastav, M.; Varghese, E. Effect of chitosan coating on postharvest life and quality of plum during storage at low temperature. Sci. Hortic. 2017, 226, 104-109. [CrossRef]

25. AOAC. Official Methods of Analysis of AOAC, 17th ed.; The Association of Official Analytical Chemists: Gaithersburg, MD, USA, 2000.

26. Singleton, V.L.; Rossi, J.A. Colorimetry of total phenolic with phosphomolybdic-phosphotungstic acid reagents. Am. J. Enol. Vitic. 1965, 16, 144-158.

27. Jiang, Y.; Lib, J.; Jiang, W. Effects of chitosan coating on shelf life of cold-stored litchi fruit at ambient temperature. LWT 2005, 38, 757-761. [CrossRef]

28. Woisky, R.G.; Salatino, A. Analysis of propolis: Some parameters and procedures for chemical quality control. J. Apic. Res. 1998, 37, 99-105. [CrossRef]

29. Shiri, M.A.; Bakhshi, D.; Ghasemnezhad, M.; Dadi, M.; Papachatzis, A.; Kalorizou, H. Chitosan coating improves the shelf life and postharvest quality of table grape (Vitis vinifera) cultivar Shahroudi. Turk. J. Agric. For. 2013, 37, 148-156. 
30. Arnnok, P.; Ruangviriyachai, C.; Mahachai, R.; Techawongstien, S.; Chanthai, S. Optimization and determination of polyphenol oxidase and peroxidase activities in hot pepper (Capsicum annuum L.) pericarb. Int. Food Res. J. 2010, 17, 385-392.

31. Aguiló-Aguayo, I.; Soliva-Fortuny, R.; Martín-Belloso, O. Color and viscosity of watermelon juice treated by high-intensity pulsed electric fields or heat. Innov. Food Sci. Emerg. Technol. 2010, 11, 299-305. [CrossRef]

32. Togrul, H.; Arslan, N. Carboxymethylcellulose from sugar beet pulp cellulose as a hydrophilic polymer in coating of mandarin. J. Food Eng. 2004, 62, 271-279. [CrossRef]

33. Chiabrando, V.; Giacalone, G. Effects of alginate edible coating on quality and antioxidant properties in sweet cherry during postharvest storage. Ital. J. Food Sci. 2015, 27, 173-180.

34. Menezes, J.; Athmaselvi, A.K. Polysaccharide based edible coating on sapota fruit. Int. Agrophys. 2016, 30, 551-557. [CrossRef]

35. Manganaris, G.A.; Vicente, A.R.; Crisosto, C.H. Effect of pre-harvest and post-harvest conditions and treatments on plum fruit quality. CAB Rev. Perspect. Agric. Vet. Sci. Nutr. Nat. Resour. 2008, 3, 3. [CrossRef]

36. Kowalczyk, D.; Kordowska-Wiater, M.; Zi, E.; Baraniak, B. Effect of carboxymethylcellulose/candelilla wax coating containing potassium sorbate on microbiological and physicochemical attributes of pears. Sci. Hortic. 2017, 218, 326-333. [CrossRef]

37. Martínez-Romero, D.; Paladines, D.; Valverde, M.; Guillén, F.; Zapata, P.J.; Valero, D. Rosehip oil added to Aloe vera gel as postharvest coating of 'Songría' plums and 'President' prunes. Acta Hortic. 2018, 1194, 321-326. [CrossRef]

38. Kumar, P.; Sethi, S.; Sharma, R.R.; Srivastav, M.; Singh, M.; Varghese, E. Edible coatings influence the cold-storage life and quality of 'Santa Rosa' plum (Prunus salicina Lindell). J. Food Sci. Technol. 2018, 55, 2344-2350. [CrossRef]

39. Zhou, R.; Mo, Y.; Li, Y.; Zhao, Y.; Zhang, G.; Hu, Y. Quality and internal characteristics of Huanghua pears (Pyrus pyrifolia Nakai. cv. Huanghua) treated with different kinds of coatings during storage. Postharvest Biol. Technol. 2008, 49, 171-179. [CrossRef]

40. Oms-Oliu, G.; Soliva-Fortuny, R.; Martin-Belloso, O. Edible coatings with antibrowning agents to maintain sensory quality and antioxidant properties of fresh-cut pears. Postharvest Biol. Technol. 2008, 50, 87-94. [CrossRef]

41. Panahirad, S.; Naghshiband-Hassani, R.; Mahna, N. Pectin-based edible coating preserves antioxidative capacity of plum fruit during shelf life. Food Sci. Technol. Int. 2020, in press. [CrossRef]

42. Mehta, S.; Soni, N.; Satpathy, G.; Gupta, R.K. Evaluation of nutritional, phytochemical, antioxidant and antibacterial activity of dried plum (Prunus domestica). J. Pharmacogn. Phytochem. 2014, 3, 166-171.

43. Aitboulahsen, M.; Zantar, S.; Laglaoui, A.; Chairi, H.; Arakrak, A.; Bakkali, M.; Zerrouk, M.H. Gelatin-based edible coating combined with Mentha pulegium essential oil as bioactive packaging for strawberries. J. Food Qual. 2018, 2018, 8408915. [CrossRef]

44. Wang, S.; Gao, H. Effect of chitosan-based edible coating on antioxidants, antioxidant enzyme system and postharvest fruit quality of strawberries (Fragaria $x$ aranassa Duch.). LWT 2013, 52, 71-79. [CrossRef]

45. Dong, H.; Cheng, L.; Tan, J.; Zheng, K.; Jiang, Y. Effects of chitosan coating on quality and shelf life of peeled litchi fruit. J. Food Eng. 2004, 64, 355-358. [CrossRef]

46. Prior, R.L.; Cao, G. Antioxidant phytochemicals in fruits and vegetables: Diet and health implications. HortScience 2000, 35, 588-592. [CrossRef]

47. Singh, S.P.; Singh, Z.; Swinny, E.E. Climacteric level during fruit ripening influences lipid peroxidation and enzymatic and non-enzymatic antioxidative systems in Japanese plums (Prunus salicina Lindell). Postharvest Biol. Technol. 2012, 65, 22-32. [CrossRef]

48. Moreira, M.R.; Alvarez, M.V.; Martin-Belloso, O.; Soliva-Fortuny, R. Effects of pulsed light treatments and pectin edible coatings on the quality of fresh-cut apples: A hurdle technology approach. J. Sci. Food Technol. 2016, 97, 261-268. [CrossRef]

49. Ali, A.; Maqbool, M.; Alderson, P.G.; Zahid, N. Effect of gum Arabic as an edible coating on antioxidant capacity of tomato (Solanum lycopersicum L.) fruit during storage. Postharvest Biol. Technol. 2013, 76, 119-124. [CrossRef]

(C) 2020 by the authors. Licensee MDPI, Basel, Switzerland. This article is an open access article distributed under the terms and conditions of the Creative Commons Attribution (CC BY) license (http://creativecommons.org/licenses/by/4.0/). 